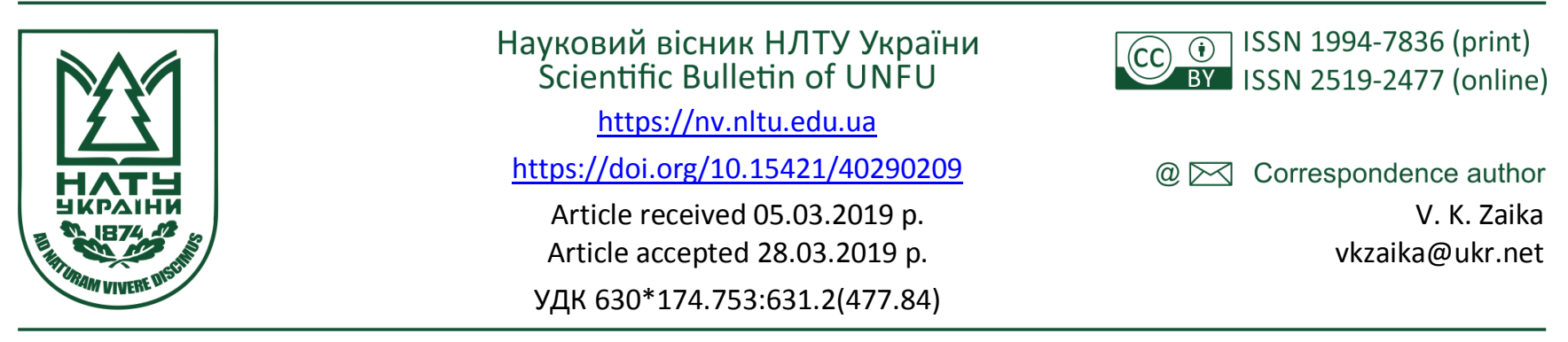

Е. І. Керімов ${ }^{1}$ В. К. Заӥка

${ }^{1}$ Кременецький лісотехнічний коледж, с. Білокриниия, Україна

${ }^{2}$ Національний лісотехнічний університет Украӥни, м. Львів, Украйна

\title{
ЛІСОВІДНОВНІ ПРОЦЕСИ В ДЕРЕВОСТАНАХ ЗА УЧАСТЮ МОДРИНИ ЄВРОПЕЙСЬКОЇ В УМОВАХ КРЕМЕНЕЦЬКОГО ГОРБОГІР'Я
}

\begin{abstract}
Досліджено лісовідновні процеси в модринових деревостанах віком від 25 до 109 років, які ростуть в умовах від бідних суборів до свіжих і вологих грудів Кременецького горбогір'я. Частка модрини у складі цих деревостанів становить 1-10 одиниць. Встановлено, що в модринових деревостанах різного віку виявлено від 2,31 до 27,89 тис. екз./га підросту деревних видів. У його складі в різних деревостанах трапляється від одного до шести деревних порід - сосни звичайної, дуба звичайного і червоного, модрини європейської, кленів гостролистого і явора, в'яза голого, бука лісового, граба звичайного, ялини європейської, а їхня кількість залежить від типу лісорослинних умов. Трапляння підросту коливається в межах 45-100 \%. Biкова структура підросту є різною і залежить від видового складу і його властивостей до виживання за недостатньої освітленості під наметом деревостанів. Однорічки трапляються на всіх дослідних ділянках у кількості 2,0-51,7 \%, 2-3-річки становлять 3,9-45,3 \%, 4-8-річки - 18,2-62,9 \% і 9-15-річки - в межах 7,2-45,8 \%. Одно- і 2-3-річний підріст сформувався переважно сосною, модриною, дубом звичайним і червоним. Кількість здорових рослин підросту в деревостанах становить від 18,8 до $47,1 \%$, середньоослаблених - 30,8-55,3\% і дуже ослаблених - 10,0-28,0 \%. У деревостанах переважає дрібний (21,9$100,0 \%)$ і середній $(0,0-77,2 \%)$ за висотою підріст. Великий підріст трапляється на окремих ділянках із часткою 0,2-7,1 \%. До дрібного підросту належить все потомство сосни, модрини, дуба звичайного і червоного та ясена. Групу середнього і великого за висотою підросту формує молоде покоління ялини, клена гостролистого і явора, в'яза голого та граба.

Ключові слова: природне поновлення; самосів; підріст; модрина європейська; деревостан.
\end{abstract}

Вступ. Введення у насадження інтродуцентів проводиться 3 метою підвищення продуктивності лісів та отримання якісної та цінної деревини. Їхня взаємодія в деревостанах з аборигенними видами повинна характеризуватись синергетичним ефектом та не допускатись антагоністичні взаємовпливи на рівні як деревостану, так i самосіву та підросту. Модрина європейська належить до видів, які широко інтродуковані в лісові насадження України різних природних зон (Belelia \& Debryniuk, 2017; Horoshko \& Savchyn, 2011; Debryniuk \& Belelia, 2012; Debryniuk, 2014; Levkovych, 2011; Cishchuk, 2012; Cishchuk, Yatsyk \& Sishchuk, 2013). Особливості iï pocту та формування деревостанів в умовах Західного Лісостепу, Західного Полісся і Карпат досліджено достатньо широко. Водночас лісовідновний потенціал цієї деревної породи вивчено слабо. Найкраще умови природного насінного поновлення модрини європейської показано в роботі С. О. Белеля і Ю. М. Дебринюка (Веlelia \& Debryniuk, 2017). Вони в Західному Поліссі виявили підріст модрини (708 екз./га) 1-4-річного віку в міжряддях лісових культур сосни, які попередню були добре оброблені грунтообробними знаряддями. Даних щодо поновлення модрини під наметом материнських деревостанів немає. Очевидно ії поновлення дуже залежить від потужності лісової підстилки та світлового режиму під наметом деревостанів.
Об'єкти і методи дослідження. Об'єктом дослідження були лісовідновні процеси в деревостанах за участю модрини європейської в умовах Кременецького горбогір'я.

Предмет дослідження - кількість підросту деревних видів, його стан, трапляння та вікова структура.

Мета дослідження - встановити особливості лісовідновних процесів у деревостанах за різною участю в їх складі модрини європейської.

Дослідження проводили в деревостанах за участю модрини європейської віком 12-109 років, які ростуть в умовах від бідних суборів до свіжих і вологих грудів Кременецького горбогір'я. Частка модрини в їх складі становить від 1-ї до 10-ти одиниць. Серед них переважають деревостани 3 часткою модрини 5-8 одиниць. Вони ростуть переважно за $\mathrm{I}^{\mathrm{a}}-\mathrm{I}^{\mathrm{d}}$ класами бонітету $(\mathrm{Be}-$ lelia \& Debryniuk, 2017).

Дослідження кількості самосіву і підросту проводили за методикою, яка часто застосовують в лісівничих дослідженнях (Vedmid, Shkudor \& Buzun, 2008; Ноroshko \& Savchyn, 2011). Для цього на кожній пробній площі закладали по 20 площадок площею по $4 \mathrm{~m}^{2}$ $(2 \times 2$ м). На кожній обліковій площадці визначали кількість самосіву і підросту, який розподіляли за деревними видами, станом і групами віку. Підріст за віком розділяли на 1-, 2-3-, 4-8- і 8-15-річки, а за висотою - на

\section{Інформація про авторів:}

Керімов Ельхан Ілхамович, викладач. Email: elhan26@rambler.ru

Заїка Володимир Костянтинович, д-р біол. наук, професор, кафедра лісівництва. Email: vkzaika@ukr.net

Цитування за ДСТУ: Керімов Е. І., Заїка В. К. Лісовідновні процеси в деревостанах за участю модрини європейської в умовах Кременецького горбогір'я. Науковий вісник НЛтУ України. 2019, т. 29, № 2. С. 47-52.

Citation APA: Kerimov, E. І., \& Zaika, V. К. (2019). Forest-regeneration processes in the stands with the participation of european larch in the conditions of the Kremenets hill area. Scientific Bulletin of UNFU, 29(2), 47-52. https://doi.org/10.15421/40290209 
групи: до 0,25; 0,26-0,50; 0,51-0,75; 0,76-1,00; 1,01-1,50; 1,51-2,00 м. Підріст висотою до 0,50 м вважається дрібний, 0,51-1,50 м - середній та 1,51 м і вище - великий. За станом підріст розділяли на здоровий, середньоослаблений і дуже ослаблений (Vedmid, Shkudor \& Buzun, 2008; Pasternak, et al., 1990).

Результати дослідження. Природне насінне поновлення лісу найбільше відповідає біологічним особливостям деревних видів, забезпечує збереження генетичного і видового розмаїття та спадкоємність поколінь, сприяє більш швидкому відновленню лісового середовища і формуванню високопродуктивних, біологічно стійких лісостанів. Результати нашого дослідження щодо процесів природного поновлення під наметом деревостанів за участю модрини європейської наведено в табл. 1.
3 табл. 1 видно, що лісовідновні процеси в дослідних деревостанах відбуваються з різною інтенсивністю. Під їх наметом ми виявили від 2,31 до 27,89 тис. екз./га підросту деревних видів. У його складі трапляється від одного до шести деревних порід, а їхня кількість залежить від типу лісорослинних умов. Так, на діл. 15 у 25річному деревостані в умовах свіжого бідного субору виявлено тільки підріст сосни в кількості 3,63 тис. екз./га. В умовах свіжих і вологих сугрудів (діл. 8, 14, $18,19)$ кількість видів у складі підросту зросла до 2-4, а в грудах - переважно трапляється 5-6 деревних порід. Окрім сосни звичайної, виявили самосів і підріст дуба звичайного, дуба червоного, модрини європейської, клена гостролистого і явора, в'яза голого, бука лісового, граба звичайного та ялини європейської.

Табл. 1. Кількість підросту деревних видів під наметом дослідних лісостанів, тис. шт./га (2015 р.)

\begin{tabular}{|c|c|c|c|c|c|c|c|c|c|}
\hline \multirow{2}{*}{$\begin{array}{l}\text { № пр. } \\
\text { пл. }\end{array}$} & \multicolumn{2}{|l|}{ Деревостан } & \multirow{2}{*}{ Порода } & \multicolumn{4}{|c|}{ Вік підросту, років } & \multicolumn{2}{|c|}{ Разом } \\
\hline & склад & вік, років & & 1 & $2-3$ & $4-8$ & $9-15$ & К-сть & $\%$ \\
\hline 1 & 2 & 3 & 4 & 5 & 6 & 7 & 8 & 9 & 10 \\
\hline 15 & 9Мдє1С3 & 25 & $\mathrm{C} 3$ & $\frac{1,88}{51,7}$ & $\frac{0,75}{20,7}$ & $\frac{1,00}{27,6}$ & - & $\frac{3,63}{100,0}$ & 100,0 \\
\hline \multirow{2}{*}{14} & \multirow{2}{*}{ 8Мдє2С3+Чш } & \multirow{2}{*}{29} & Яле & - & - & 0,50 & 1,00 & 1,50 & 54,5 \\
\hline & & & $\mathrm{C} 3$ & 0,75 & 0,50 & - & - & 1,25 & 45,5 \\
\hline & Всього & & & $\frac{0,75}{27,3}$ & $\frac{0,50}{18,2}$ & $\begin{array}{l}0,50 \\
18,2\end{array}$ & $\frac{1,00}{36,4}$ & $\frac{2,75}{100,0}$ & \\
\hline \multirow{4}{*}{8} & \multirow{4}{*}{$\begin{array}{c}\text { 7Мдє3Ясз+Дз, Гз, Клг, } \\
\text { Взг, Лпд }\end{array}$} & \multirow{4}{*}{56} & $\mathrm{C}_{3}$ & 0,57 & 0,43 & - & - & 1,00 & 29,6 \\
\hline & & & Д3 & 0,28 & - & - & - & 0,28 & 8,3 \\
\hline & & & Клг & - & 0,25 & 0,63 & 0,73 & 1,61 & 47,6 \\
\hline & & & В3г & - & 0,36 & 0,13 & - & 0,49 & 14,5 \\
\hline & Всього & & & $\frac{0,85}{25,1}$ & $\frac{1,04}{30,8}$ & $\frac{0,76}{22,5}$ & $\frac{0,73}{21,6}$ & $\frac{3,38}{100,0}$ & \\
\hline \multirow{4}{*}{18} & \multirow{4}{*}{$\begin{array}{c}\text { 6Мдє3 Дз1Клг+Кля, Лпд, } \\
\text { Взг, Гз, Бп }\end{array}$} & \multirow{4}{*}{43} & $\mathrm{C}_{3}$ & 0,87 & 0,48 & - & - & 1,35 & 24,0 \\
\hline & & & Яле & - & - & 0,63 & 0,96 & 1,59 & 28,3 \\
\hline & & & Клг & - & 0,53 & 0,43 & 0,12 & 1,08 & 19,2 \\
\hline & & & $\Gamma 3$ & - & - & 0,74 & 0,85 & 1,59 & 28,4 \\
\hline & Всього & & & $\frac{0,87}{15,5}$ & $\frac{1,01}{18,1}$ & $\frac{1,79}{32,0}$ & $\frac{1,93}{34,5}$ & $\frac{5,61}{100,0}$ & \\
\hline \multirow{3}{*}{19} & \multirow{3}{*}{$\begin{array}{c}\text { 6Мдє2Бп1Дз 1Гз+Вхч, } \\
\text { Клг, Лпд }\end{array}$} & \multirow{3}{*}{50} & Д3 & 0,63 & - & - & - & 0,63 & 16,1 \\
\hline & & & Клг & - & 1,00 & 1,25 & - & 2,25 & 51,6 \\
\hline & & & $\Gamma_{3}$ & - & - & 1,50 & - & 1,50 & 32,3 \\
\hline & Всього & & & $\frac{0,63}{14,3}$ & $\frac{1,00}{22,9}$ & $\frac{2,75}{62,9}$ & $\begin{array}{ll}- \\
-\end{array}$ & $\frac{4,38}{100,0}$ & \\
\hline \multirow{5}{*}{11} & \multirow{5}{*}{$\begin{array}{c}\text { 4Мдг3Кля1Ясз1Дч1Вхч+ } \\
\text { Дз, Взг, Гз, Кляс, Бп }\end{array}$} & \multirow{5}{*}{31} & Дч & 2,13 & 1,88 & - & - & 4,00 & 29,1 \\
\hline & & & Клг & 1,38 & 1,90 & 0,88 & - & 4,16 & 30,0 \\
\hline & & & Кля & - & 0,75 & 1,25 & - & 2,00 & 14,5 \\
\hline & & & В3г & - & 0,38 & 1,50 & - & 1,88 & 13,6 \\
\hline & & & $\Gamma 3$ & - & - & 1,75 & - & 1,75 & 12,7 \\
\hline & Всього & & & $\frac{3,50}{25,5}$ & $\frac{4,90}{35,5}$ & $\frac{5,38}{39,1}$ & - & $\frac{13,79}{100,0}$ & \\
\hline \multirow{6}{*}{10} & & & Дч & 4,38 & 4,00 & 2,88 & - & 11,25 & 40,4 \\
\hline & & & Мдє & 1,13 & - & - & - & 1,13 & 4,0 \\
\hline & 8Дч1Мдє1Бкл+Кля, Ясз, & 16 & Клг & - & 2,00 & 2,50 & - & 4,50 & 16,1 \\
\hline & Гз, Взг, Лпд & 40 & Кля & - & 1,13 & 2,00 & 2,00 & 5,13 & 18,4 \\
\hline & & & В3г & - & - & 1,25 & - & 1,50 & 5,4 \\
\hline & & & $\Gamma 3$ & - & 1,50 & 1,38 & 1,50 & 4,38 & 15,7 \\
\hline & Всього & & & $\frac{5,50}{19,7}$ & $\frac{8,63}{30,9}$ & $\frac{10,00}{35,9}$ & $\frac{3,75}{13,5}$ & $\frac{27,89}{100,0}$ & \\
\hline & & & Мдє & 0,63 & - & - & - & 0,63 & 8,2 \\
\hline 17 & 10Мдє+Дз, Ясз, Лпд, & 50 & Дз & 1,13 & 0,38 & - & - & 1,50 & 19,7 \\
\hline 17 & Клг, Гз & 50 & Клг & - & 1,25 & 1,88 & - & 3,13 & 41,0 \\
\hline & & & $\Gamma 3$ & $=$ & & 1,38 & 1,00 & 2,38 & 31,1 \\
\hline & Всього & & & $\frac{1, \overline{75}}{23,0}$ & $\frac{1,63}{21,3}$ & $\frac{3,26}{42,6}$ & $\frac{0,12}{7,2}$ & $\frac{7,64}{100,0}$ & \\
\hline & & & Дч & 2,25 & 1,75 & - & - & 3,75 & 31,6 \\
\hline & & & Д3 & 1,13 & 1,00 & - & - & 2,13 & 17,9 \\
\hline 5 & 2Мдє2Ясз2Дч2Клг 1Дз1Г & 51 & Клг & - & 1,13 & 0,75 & - & 1,88 & 15,8 \\
\hline J & 3+Взг, Лпд & 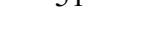 & Кля & - & & 1,00 & - & 1,00 & 8,4 \\
\hline & & & Взг & - & 0,50 & 0,38 & $\begin{array}{llll}- & \end{array}$ & 0,88 & 7,4 \\
\hline & & & $\Gamma 3$ & - & 1,00 & 1,25 & - & 2,25 & 18,9 \\
\hline & Всього & & & $\frac{3,38}{28,4}$ & $\frac{5,38}{45,3}$ & $\frac{3,38}{28,4}$ & - & $\frac{11,89}{100,0}$ & \\
\hline
\end{tabular}




\begin{tabular}{|c|c|c|c|c|c|c|c|c|c|}
\hline 1 & 2 & 3 & 4 & 5 & 6 & 7 & 8 & 9 & 10 \\
\hline \multirow{5}{*}{2} & \multirow{5}{*}{ 9Мє1Кля+Клг, Бп, Гз } & \multirow{5}{*}{52} & Мдє & 1,25 & - & - & - & 1,25 & 15,6 \\
\hline & & & Клг & - & 0,88 & 0,88 & - & 1,75 & 21,9 \\
\hline & & & Кля & - & 0,50 & 1,13 & - & 1,63 & 20,3 \\
\hline & & & В3г & - & 0,50 & 1,00 & - & 1,50 & 18,8 \\
\hline & & & $\Gamma 3$ & - & & 1,88 & - & 1,88 & 23,4 \\
\hline & Всього & & & $\frac{1,25}{15,6}$ & $\frac{1,88}{23,5}$ & $\frac{4,88}{60,9}$ & & $\frac{8,01}{100,0}$ & \\
\hline \multirow{6}{*}{7} & \multirow{6}{*}{ 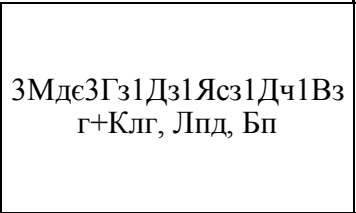 } & \multirow{6}{*}{52} & Дч & 1,25 & 1,50 & - & - & 2,75 & 21,0 \\
\hline & & & Д3 & 0,38 & 0,75 & - & - & 1,13 & 8,6 \\
\hline & & & Клг & - & 1,13 & 0,88 & - & 2,00 & 15,2 \\
\hline & & & Кля & - & 0,63 & 1,00 & 0,75 & 2,38 & 18,1 \\
\hline & & & В3г & - & & 1,00 & 0,75 & 1,75 & 13,3 \\
\hline & & & $\Gamma 3$ & - & 1,50 & 1,00 & 0,63 & 3,13 & 23,8 \\
\hline & Всього & & & $\begin{array}{l}1,63 \\
12,4\end{array}$ & $\frac{5,50}{41,9}$ & $\frac{3,88}{29,5}$ & $\frac{2,13}{16,2}$ & $\frac{13,14}{100,0}$ & \\
\hline \multirow{6}{*}{12} & \multirow{6}{*}{$\begin{array}{c}5 \mathrm{Mдє4Дз1Гз+Клг,} \mathrm{Кля,} \\
\text { Лпд }\end{array}$} & \multirow{6}{*}{53} & Мдє & 0,88 & - & - & - & 0,88 & 8,2 \\
\hline & & & Д3 & 1,63 & 1,13 & - & - & 2,75 & 25,9 \\
\hline & & & Клг & 0,63 & & 0,75 & - & 1,38 & 12,9 \\
\hline & & & Кля & & 0,88 & & 0,50 & 1,38 & 12,9 \\
\hline & & & В3г & - & - & 1,38 & 0,63 & 2,00 & 18,8 \\
\hline & & & $\Gamma 3$ & - & - & 1,63 & 0,63 & 2,25 & 21,2 \\
\hline & Всього & & & $\frac{3,14}{29,4}$ & $\frac{2,01}{18,8}$ & $\frac{3,76}{35,3}$ & $\frac{1,76}{16,5}$ & $\frac{10,64}{100,0}$ & - \\
\hline \multirow{6}{*}{1} & \multirow{6}{*}{$\begin{array}{c}\text { 5Мє2Ясз1Дз1Кля1Бха }+К \\
\text { лг, Взг, Гз }\end{array}$} & \multirow{6}{*}{58} & Я $_{3}$ & 0,88 & - & - & - & 0,88 & 7,4 \\
\hline & & & Д3 & 1,25 & 0,88 & - & - & 2,13 & 18,1 \\
\hline & & & Клг & 0,50 & 0,50 & 0,88 & - & 1,88 & 16,0 \\
\hline & & & Кля & 0,38 & 0,63 & 0,88 & 0,75 & 2,63 & 22,3 \\
\hline & & & В3г & & 0,50 & 0,75 & 0,63 & 1,88 & 16,0 \\
\hline & & & $\Gamma 3$ & 0,38 & & 1,38 & 0,63 & 2,38 & 20,2 \\
\hline & Всього & & & $\frac{3,39}{28,7}$ & $\frac{2,50}{21,3}$ & 33,89 & $\frac{2,00}{17,0}$ & $\frac{11,78}{100,0}$ & \\
\hline \multirow{4}{*}{9} & \multirow{4}{*}{$\begin{array}{c}\text { 7Мдє1Ялє1Ясз1Клг+Взг, } \\
\text { Лпд, Гз }\end{array}$} & \multirow{4}{*}{60} & Яле & - & 0,50 & 0,75 & - & 1,25 & 14,3 \\
\hline & & & Клг & 0,75 & 0,63 & 1,38 & - & 2,75 & 31,4 \\
\hline & & & В3г & - & - & 1,00 & 1,00 & 2,00 & 22,9 \\
\hline & & & $\Gamma_{3}$ & 0,50 & - & 1,25 & 1,00 & 2,75 & 31,4 \\
\hline \multicolumn{2}{|r|}{ Всього } & & & $\frac{1,25}{14,3}$ & $\frac{1,13}{12,9}$ & $\frac{4,38}{50,0}$ & $\frac{0,64}{25,4}$ & $\frac{8,75}{100,0}$ & \\
\hline \multirow{4}{*}{4} & \multirow{4}{*}{ 6Мдє3Дз1Взг+Кля, Гз } & \multirow{4}{*}{84} & Д3 & 0,35 & 0,18 & - & - & 0,53 & 22,9 \\
\hline & & & Кля & - & - & 0,10 & 0,15 & 0,25 & 10,8 \\
\hline & & & В3г & - & - & 0,21 & 0,55 & 0,76 & 32,9 \\
\hline & & & $\Gamma 3$ & - & - & 0,48 & 0,29 & 0,77 & 33,3 \\
\hline & Всього & & & $\frac{0,35}{15,2}$ & $\frac{0,18}{7,8}$ & $\frac{0,79}{34,2}$ & $\frac{0,99}{42,9}$ & $\frac{2,31}{100,0}$ & \\
\hline & & & Д3 & 0,58 & - & - & - & 0,58 & 19,0 \\
\hline & & & Бкл & - & - & 0,82 & 0,25 & 1,07 & 35,1 \\
\hline 16 & /МДЕСАсЗ ДЗЬКЛ+КЛГКЛ & 101 & Клг & - & - & 0,12 & 0,10 & 0,22 & 7,2 \\
\hline & & & Кля & - & - & 0,15 & 0,24 & 0,39 & 12,8 \\
\hline & & & Г3 & - & 0,45 & 0,18 & 0,16 & 0,79 & 25,9 \\
\hline & Всього & & & $\frac{0,58}{19,0}$ & $\frac{0,45}{14,8}$ & $\frac{1,27}{41,6}$ & $\frac{0,75}{24,6}$ & $\frac{3,05}{100,0}$ & \\
\hline & & & Д3 & 0,22 & - & - & - & 0,22 & 2,0 \\
\hline & & & Клг & - & 0,42 & 2,07 & 1,12 & 3,61 & 33,2 \\
\hline 3 & 8Мдє1Дз, Ясз1Гз+Клг & 109 & Кля & - & - & 1,68 & 1,95 & 3,63 & 33,4 \\
\hline & & & В3г & - & - & 0,62 & 0,88 & 1,50 & 13,8 \\
\hline & & & $\Gamma 3$ & 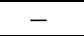 & - & 0,88 & 1,03 & 1,91 & 17,6 \\
\hline & Всього & & & $\frac{0,22}{2,0}$ & $\frac{0,42}{3,9}$ & $\frac{5,25}{48,3}$ & $\frac{4,98}{45,8}$ & $\frac{10,87}{100,0}$ & \\
\hline
\end{tabular}

Примітка: У чисельнику - фактичні значення (тис. шт./га), у знаменнику - відносні (\%).

Найменшу кількість підросту деревних видів (2,314,38 екз./га) виявили на діл. 4, 8, 14, 15, 16, 19. Вони характеризуються різним віком та іншими лісівничо-таксаційними показниками. Так, на ділянках 14 і 15 ростуть молодняки віком 25-29 років, на 8,19 - середньовікові, а на 4, 16 - стиглі та перестиглі деревостани (Debryniuk, 2014). Вони також істотно відрізняються повнотою, яка змінюється в межах 12,6-48,2 м²/га. Середніми показниками кількості підросту (в межах 5,110,0 тис. екз./га) характеризуються деревостани на пр. пл. 18, 2, 9 і значними (понад 10 тис. екз./га) - на діл. 1, $3,5,7,10,11,12$.
Сосна звичайна у складі підросту трапляється в деревостанах на пр. пл. $8,14,15,18$. На діл. $8,14,18$ у складі підросту їі частка становить $24,0-45,5 \%$. Він належить до вікових груп 1- і 2-3-річок і не здатний під наметом материнських деревостанів сформувати молоде покоління лісу (Zaika, Krynytskyi \& Ivanytskyi, 2013). Водночас необхідно відзначити більш успішне поновлення ялини європейської в деревостані на пр. пл. 14 , яка досягає 4-8-річного віку і старше, а її частка становить 54,5\% та деяких інших деревних видів (рис. 1,2). 


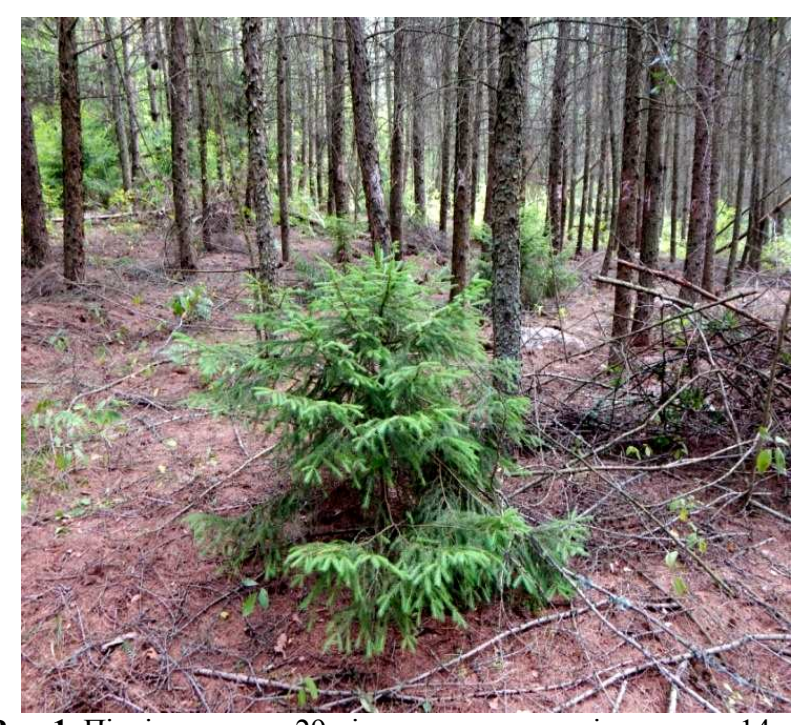

Рис. 1. Підріст ялини у 29-річному деревостані на пр. пл. 14

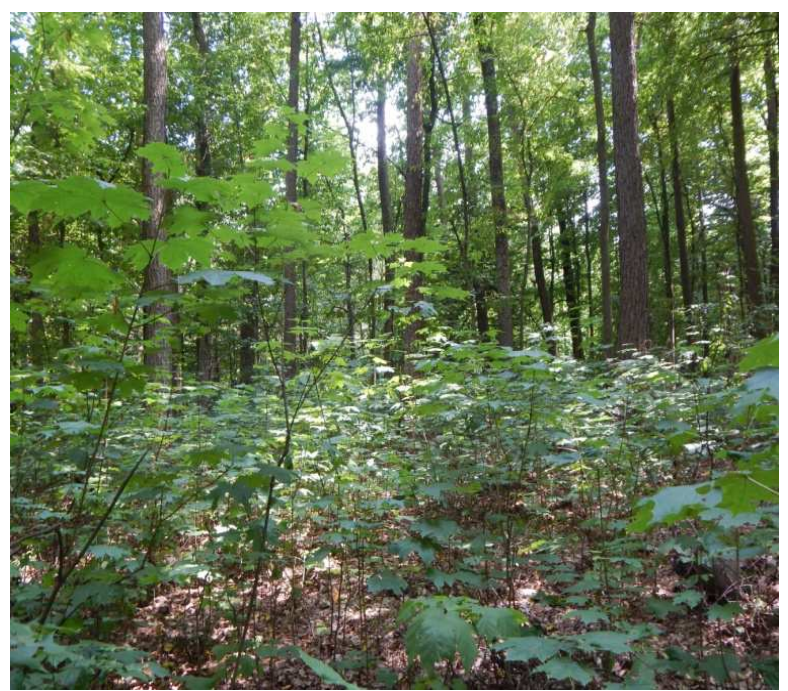

Рис. 2. Підріст деревних видів у 109-річному деревостані на пр. пл. 3

Загалом вікова структура підросту в деревостанах $є$ різною і залежить від складу деревних видів, які його сформували, і ї здатності до виживання за недостатньої освітленості під наметом деревостанів. Однорічки трапляються на всіх дослідних ділянках у кількості 2,0-51,7\%. Більшою мірою в деревостанах поширені види 2-3-річного (3,9-45,3\%) і 4-8-річного $(18,2-$ $62,9 \%)$ віку. Підріст віком 9-15 років трапляється на $71 \%$ дослідних ділянок. Його частка у видовому складі коливається в межах 7,2-45,8 \%. Одно- і 2-3-річний підріст сформувався переважно сосною, модриною, дубом звичайним і червоним. Він під наметом деревостанів $\epsilon$ не довговічним. Сосна 4-8-річного віку трапилась тільки на ділянці 15 в умовах перехідного типу лісорослинних умов від $\mathrm{A}_{2}$ до $\mathrm{B}_{2}$. Модрина на половині цієї ділянки випала і створився сприятливий світловий режим для росту підросту сосни звичайної. Підріст модрини європейської трапляється тільки на окремих ділянках однорічного віку. Його частка становить 4,0-15,6 \%. На нашу думку, модрина європейська не здатна відновитись природним насінним способом у дослідних лісостанах через високу світлолюбність. Дуб звичайний також характеризується незадовільним природним поновленням і особливо виживанням підросту. Його підріст не перевищує 2-3-річного віку. Частка у складі на різних ділянках коливається в межах 2,0-25,9\%. Необхід- но зазначити інтенсивне поновлення в окремих деревостанах дуба червоного, де його частка досягає 21,0 40,4 \%. Переважно він належить до одно- і 2-3-річного віку. Найбільша кількість підросту дуба червоного $(11,25$ тис. екз./га) виявилась в деревостані на пр. пл. 10 , де значна його кількість $(2,88$ тис. екз./га) належить до вікової групи 4-8-років.

Підріст 4-8-річного і старшого віку формується завдяки поновленню клена гостролистого і явора, в'яза голого і граба звичайного, а на окремих ділянках ялини європейської. Ці деревні види не тільки добре поновлюються природним насінним шляхом, а й їх підріст характеризується відносно високою тіневитривалістю та здатністю рости в умовах низької освітленості під наметом деревостанів. Найбільшу кількість підросту $(98,0$ \%) кленів, в'яза і граба старших вікових груп (4-8 i 9-15 років) виявлено в модриновому деревостані на пр. пл. 3 (див. рис. 2). Він характеризується добрим ростом і станом завдяки достатньої кількості світла, яке приникає через лісовий намет модринового деревостану.

Важливим показником проходження лісовідновних процесів є трапляння підросту деревних видів (табл. 2). Загалом для всіх видів цей показник на дослідних ділянках коливається у широких межах від 45 до $100 \%$. У значної кількості деревостанів його показники виявились високими (90-100 \%). Трапляються також деревостани (пр. пл. 4,8 ), де підріст становить на менше половини площадок, що свідчить про нерівномірність природного поновлення деревних видів.

Табл. 2. Стан підросту деревних видів та його трапляння

\begin{tabular}{|c|c|c|c|c|}
\hline \multirow{2}{*}{$\begin{array}{c}\text { № пр. } \\
\text { пл. }\end{array}$} & \multicolumn{3}{|c|}{ Стан } & Трапляння, \\
\cline { 2 - 4 } & здорові & $\begin{array}{c}\text { середньо } \\
\text { ослаблені }\end{array}$ & $\begin{array}{c}\text { дуже } \\
\text { ослаблені }\end{array}$ & \\
\hline 15 & 18,8 & 55,3 & 25,9 & 65 \\
\hline 14 & 36,4 & 35,6 & 28,0 & 60 \\
\hline 8 & 36,7 & 50,9 & 12,5 & 45 \\
\hline 18 & 34,4 & 47,0 & 18,5 & 65 \\
\hline 19 & 50,2 & 30,8 & 19,0 & 70 \\
\hline 11 & 40,7 & 44,4 & 14,9 & 90 \\
\hline 10 & 31,0 & 45,6 & 23,4 & 100 \\
\hline 17 & 35,6 & 45,0 & 19,4 & 90 \\
\hline 5 & 33,5 & 45,6 & 20,9 & 90 \\
\hline 2 & 34,2 & 52,3 & 13,5 & 95 \\
\hline 7 & 36,7 & 47,5 & 15,8 & 100 \\
\hline 12 & 40,3 & 44,6 & 15,1 & 95 \\
\hline 1 & 35,5 & 49,7 & 14,8 & 100 \\
\hline 9 & 42,9 & 47,0 & 10,0 & 90 \\
\hline 4 & 43,3 & 45,3 & 11,4 & 45 \\
\hline 16 & 32,9 & 48,3 & 18,8 & 55 \\
\hline 3 & 47,1 & 41,4 & 11,5 & 75 \\
\hline
\end{tabular}

Трапляння підросту окремих деревних видів у межах дослідних деревостанів характеризується високою строкатістю та становить 15-65\%. Тільки у підросту дуба червоного на пр. пл. 10 і 11 його показник досягає 70-85\%. Значні коливання показника трапляння спостерігаємо навіть у таких видів, як: клен гостролистий, клен-явір і граб. Рівномірність поновлення деревних видів значно залежить від розташування дерев у деревостані та особливостей поширення їхнього насіння.

Висока ймовірність формування молодого покоління лісу залежить від фізіологічного стану підросту. Серед підросту деревних видів кількість здорових рослин у деревостанах змінюється від 18,8 (пр. пл. 15) до 47,1 \% (пр. пл. 3), а кількість дуже ослаблених екземплярів становить 10,0-28,0 \% (див. табл. 2). Загалом під наметом деревостанів переважають здорові та се- 
редньоослаблені потомства дерев. Розподіл підросту деревних видів за висотами наведено в табл. 3

Табл. 3. Розподіл підросту за висотою, \%

\begin{tabular}{|c|c|c|c|c|c|c|}
\hline \multirow{2}{*}{$\begin{array}{c}\text { № } \\
\text { пр. } \\
\text { пл. }\end{array}$} & \multicolumn{7}{|c|}{ Во 0,25} & $0,26-0,50$ & $0,51-0,75$ & $0,76-1,0$ & $1,01-1,51$ & $1,51-2,00$ \\
\hline 15 & 66,7 & 22,3 & 11,0 & - & - & - \\
\hline 14 & 45,5 & 0,0 & 0,0 & 23,0 & 24,4 & 7,1 \\
\hline 8 & 54,5 & 31,7 & 13,7 & - & - & - \\
\hline 18 & 31,3 & 25,8 & 30,7 & 12,3 & - & - \\
\hline 19 & 32,3 & 67,7 & - & - & - & - \\
\hline 11 & 49,5 & 41,2 & 9,3 & - & - & - \\
\hline 10 & 65,2 & 29,5 & 5,2 & 0,1 & - & - \\
\hline 17 & 47,8 & 50,1 & 2,1 & - & - & - \\
\hline 5 & 59,7 & 39,1 & 1,3 & - & - & - \\
\hline 2 & 44,3 & 39,0 & 16,7 & - & - & - \\
\hline 7 & 34,9 & 25,1 & 21,2 & 11,3 & 5,5 & 2,0 \\
\hline 12 & 48,2 & 5,7 & 27,4 & 12,8 & 5,8 & 0,2 \\
\hline 1 & 59,9 & 16,7 & 10,4 & 10,7 & 2,2 & - \\
\hline 9 & 42,3 & 24,5 & 24,8 & 7,7 & 0,8 & - \\
\hline 4 & 22,9 & 20,9 & 49,2 & 6,9 & - & - \\
\hline 16 & 33,7 & 33,5 & 22,9 & 9,5 & 0,4 & - \\
\hline 3 & 19,0 & 2,9 & 38,5 & 36,4 & 2,3 & 0,8 \\
\hline
\end{tabular}

3 табл. 3 видно, що в більшості деревостанів трапляється підріст висотою до 1 м. У значно меншої кількості деревостанів виявлено підріст висотою 1,01$1,50 \mathrm{~cm}$ і ще в меншої - висотою 1,51-2,00 м. Загалом переважає дрібний і середній за висотою підріст. До дрібного підросту (висотою до 50 см) належить весь підріст сосни, модрини, дуба звичайного і червоного та ясена звичайного. Зазвичай це рослини однорічного віку висотою до 25 см. $€$ серед них значно менша кількість екземплярів 2-3-річного віку, частина з яких характеризується висотою в межах $26-50$ см. Групу середнього і великого за висотою підросту формує підріст ялини, клена гостролистого і явора, в'яза голого та граба. Необхідно зазначити, що крупний підріст трапляється на окремих ділянках (пр. пл. 3, 7, 12, 14) і представлений ялиною, грабом, в'язом і кленом гостролистим.

Висновки:

1. Під наметом модринових деревостанів різного віку виявлено від 2,31 до 27,89 тис. екз./га підросту деревних видів. У його складі в деревостанах трапляється від одного до шести деревних порід (сосна звичайна, дуб звичайний i червоний, модрина європейська, клени гостролистий і явір, в'яз голий, бук лісовий, граб звичайний, ялина європейська), а їхня кількість залежить від типу лісорослинних умов. Трапляння підросту на ділянках становить $45-100 \%$

2. Вікова структура підросту в деревостанах є різною і залежить від складу деревних видів, які його сформували, i їх здатності до виживання за недостатньої освітленості під наметом деревостанів. Однорічки трапляються на всіх дослідних ділянках у кількості 2,0-51,7 \%, 23 -річки становлять 3,9-45,3 \%, 4-8-річки - 18,2-62,9 \% і 9-15-річки коливаються в межах 7,2-45,8 \%. Одно- і 2- 3-річний підріст сформувався переважно сосною, модриною, дубом звичайним і червоним.

3. Кількість здорових рослин підросту в деревостанах змінюється від 18,8 \% до 47,1 \%, середньо ослаблених 30,8-55,3 \% і дуже ослаблених - 10,0-28,0 \%.

4. У деревостанах переважає дрібний $(21,9-100,0 \%)$ i ceредній $(0,0-77,2 \%)$ за висотою підрости. Великий підріст трапляється на окремих ділянках із часткою 0,27,1 \%. До дрібного підросту належить весь підріст сосни, модрини, дуба звичайного і червоного та ясена звичайного. Групу середнього і великого за висотою підросту формує підріст ялини, клена гостролистого і явора, в'яза голого та граба.

5. Модрина європейська в умовах Кременецького горбогір'я поновлюється незадовільно, а його самосів виживає під наметом деревостанів не більше одного року. Вона не здатна відновитись самостійно і сформувати деревостан.

\section{Перелік використаних джерел}

Belelia, S. O., \& Debryniuk, Yu. M. (2017). Kultyvuvannia vydiv rodu Larix L. u shtuchnykh nasadzhenniakh Zakhidnoho Polissia Ukrainy. Lviv: Halytska vydavnycha spilka, 444 p. [In Ukrainian].

Cishchuk, N. M. (2012). Lisivnycho-selektsiina otsinka modryny yevropeiskoi na pivnichnomu mehaskhyli Ukrainskykh Karpat. Abstract of Candidate Dissertation for Agricultural Sciences (06.03.01 - Forest Crops and Phytomelioration). Lviv, 20 p. [In Ukrainian].

Cishchuk, N. M., Yatsyk, R. M., \& Sishchuk, M. M. (2013). Kharakterystyka nasadzhen modryny yevropeiskoi ta dosvid yikh stvorennia u lisakh pivnichnoho mehaskhylu Ukrainskykh Karpat. Scientific Bulletin of UNFU, 20(6), 64-70. [In Ukrainian].

Debryniuk, Yu. M. (2014). Rozpovsiudzhennia ta formove rozmaittia Larix decidua Mill. Pratsi naukovoho tovarystva im. Shevchenka. Ekolohichnyi zbirnyk, 39, 181-192. [In Ukrainian].

Debryniuk, Yu. M., \& Belelia, S. O. (2012). Rozpovsiudzhennia modryny u lisovykh nasadzhenniakh Ukrainy. Proceedings of the Forestry Academy of Sciences of Ukraine, 10, 55-65. [In Ukrainian].

Horoshko, M. P., \& Savchyn, V. M. (2011). Poshyrennia riznykh vydiv modryn u shtuchnykh nasadzhenniakh Zakhidnoho Lisostepu Ukrainy. Scientific Bulletin of UNFU, 21(18), 12-17. [In Ukrainian].

Levkovych, D. B. (2011). Perspektyvy vvedennia modryny yevropeiskoi u lisovi kultury Zakhidnoho Lisostepu Ukrainy. Tezy dop. uchasnykiv mizhnar. nauk.-praktych. konf. nauk.-pedahoh. pratsivn., nauk. spivrob. ta molodykh vchenykh, (pp. 73-74). Navch.-nauk. inst-t lisovoho i sadovo-parkovoho hosp-va NUBiP Ukrainy. Kyiv: NUBiP Ukrainy. [In Ukrainian].

Pasternak, P. S. (Ed.), Molotkov, P. I., Patlai, I. N., et al. (1990). Spravochnik lesovoda. Kyiv: Urozhai, 296 p. [In Russian].

Vedmid, M. M., Shkudor, V. D., \& Buzun, V. O. (2008). Vidnovlennia pryrodnykh lisostaniv Zakhidnoho Polissia. Zhytomyr: Polissia, 304 p. [In Ukrainian].

Zaika, V. K., Krynytskyi, H. T., \& Ivanytskyi, R. S. (2013). Pryrodne zalisennia ta lisivnycho-ekolohichni i morfofiziolohichni osoblyvosti formuvannia lisostaniv na pokynutykh silskohospodarskykh zemliakh Pivnichno-zakhidnoho Podillia. Proceedings of the Forestry Academy of Sciences of Ukraine, 11, 41-50. [In Ukrainian].

E. I. Kerimov', V. K. Zaika ${ }^{2}$

${ }^{I}$ Kremenetskiy Forestry College, Bilokrynytsya, Ukraine ${ }^{2}$ Ukrainian National Forestry University, Lviv, Ukraine

\section{FOREST-REGENERATION PROCESSES IN THE STANDS WITH THE PARTICIPATION OF EUROPEAN LARCH IN THE CONDITIONS OF THE KREMENETS HILL AREA}

Investigated are forest-regeneration processes in larch stands of age from 25 to 109 years whose growing conditions vary from fairly infertile pine site types to fresh and moist fairly fertile site types of the Kremenets hill area. The share of larch in these stands ranges from 1 to 10 units. The amount of young growth was investigated by establishment in each experimental plot of 20 sites with an area of $4 \mathrm{~m} 2$ each and distribution by tree species, age, condition and height. It was found that in larch stands of different ages, there are from 2.31 to 27.89 thousand pcs/ha of young growth of woody species. The composition of young growth in different forest 
stands include from one to six tree species of Scots pine, common and red oak, European larch, Norway maple and sycamore, European white elm, European beech, hornbeam, Norway spruce. The number of species also depends on the type of forest site conditions. The occurrence of young growth on the sites varies within 45-100\%. It is found that the age structure of the young growth in the stands is different and depends on the composition of the tree species that formed it and the ability to survive at low-level illumination under the canopy of the stands. One-year-old seedlings occur on all experimental sites with a share of 2.0-51.7\%, 2-3-year-old trees fluctuate within 3.9-45.3\%, 4-8-year-old trees - 18.2-62.9\%, and 9 -15-year-old trees - 7.2-45.8 \%. One- and 2-3-year-old growth was formed mainly by pine, larch, common and red oak. The number of vigorious plants in the young growth of the stands varies from 18.8 to $47.1 \%$, the medium weakened $-30.8-55.3 \%$, and severely weakened $-10.0-28.0 \%$. The stands are dominated by young growth of short (21.9-100.0\%) and average (0.0-77.2\%) heights. Large growth occurs on some sites with a share of $0.2-$ $7.1 \%$. The young growth of short height includes the whole growth of pine, larch, common and red oak, and ash. The group of the growth of medium and tall heights is formed by the progeny of spruce, Norway maple, sycamore, European white elm, and hornbe$\mathrm{am}$. The renewal of European larch in the conditions of the Kremenets hill area is unsatisfactory, and its self-seeding is found only in separate forest stands, it survives under their canopy for no more than one year. It is not capable of self-renewal and forming stands in conditions of the Kremenets hill area.

Keywords: natural regeneration; self-seeding; European larch; forest stand. 